\title{
Regional financial disparity in India: can it be measured?
}

\author{
Rashmi U. Arora* and P. B. Anand \\ Faculty of Management, Law \& Social Sciences, University of Bradford, Bradford, UK \\ ${ }^{*}$ Corresponding author. Email: r.arora6@bradford.ac.uk
}

(Received 25 November 2019; revised 7 April 2021; accepted 8 April 2021)

\begin{abstract}
In this study, we examine disparities in financial development at the regional level in India. The major research questions of the study are: how do we measure the level of financial development at the subnational level? How unequal is financial development across the states? Does it vary by ownership of financial institutions? To explore these research questions, our study develops a composite banking development index at the sub-national level for three different bank groups - public, private and foreign for 25 Indian states covering 1996-2015. Our findings suggest that despite reforms, banking development is significantly higher in the leading high income and more developed regions compared to lagging ones. Furthermore, we find that all bank groups including public banks are concentrated more in the developed regions. Overall, over the years the position of top three and bottom three states in the aggregate banking index have remained unchanged reflecting lop-sidedness of regional development. We also note improvement in the ranking of some north-eastern states during the period 2009-15.
\end{abstract}

Key words: Banking development index; financial development; financial inclusion; India

JEL codes: D63; G21; O16; O53

\section{Introduction}

Recent discussions on inequality have focused on increasing global income and wealth inequality between individuals, inequality between countries and inequality among different population groups within a country (Atkinson, 2015; Pickety, 2014; Stiglitz, 2013, 2015). Spatial inequality, i.e. inequality over geographic regions has also been receiving some attention (Kanbur and Venables, 2005). However, inequality in the financial sector remains less explored.

In this study, we examine financial development at the sub-national level. Our major research questions are: how do we measure the level of financial development at the sub-national level? How unequal is the financial development across the states? Does it vary by the ownership of financial institutions? We examine these in the context of a large country, India. To explore the research questions, our study develops a banking development index at the sub-national level for three different bank groups - public, private and foreign for 25 Indian states covering 1996-2015. For analytical purposes following Arora and Wondemu (2018), we group states into leading and lagging. States with per capita incomes above the national average are leading, whereas those below are lagging (Appendix A).

India is an interesting case to examine as it presents a picture of marked diversity with the subnational units at different stages of development (Dreze and Sen, 2013; Frankel, 2005). Although some states (Kerala) have development levels somewhat similar to those of developed countries, others significantly lag. ${ }^{1}$ Since the economic reforms in 1991, regional disparities appear to have increased significantly (Kurian, 2000).

\footnotetext{
${ }^{1}$ These disparities existed historically as western and southern states were ahead of other regions especially in irrigation development and social indicators.

(C) Millennium Economics Ltd 2021. This is an Open Access article, distributed under the terms of the Creative Commons Attribution licence (http://creativecommons.org/licenses/by/4.0/), which permits unrestricted re-use, distribution, and reproduction in any medium, provided the original work is properly cited.
} 
Inequalities have been persistent in the level of financial development across the states. Several policies, especially those targeted at the financial sector, were adopted in the 1960s and 1970s to promote balanced regional development (Narasimham Committee Report, 1991; RBI, 2008). These included social control and nationalisation of banks in 1969 and 1980, investments in less developed regions, directed lending, insistence of $60 \%$ credit-deposit ratios for rural and semi-urban areas and establishment of Regional Rural Banks (RRBs).

Furthermore, financial development is crucial for the development of business and private sectors. An International Monetary Fund (IMF) study noted that Indian firms depend significantly on external sources of finance (Oura, 2008) and therefore, poor access to banks can limit the sources of finance for business growth in the lagging states.

Our study contributes to the existing literature in several respects. First, our study is at the subnational level and overcomes some limitations of cross-country/national level studies. In a large diverse country, sub-national picture could be very different from that at the national level. Second, we build unique state level banking development index summarising diverse information on various indicators. This allows comprehensive assessment of the state of financial development in Indian states. Third, we consider three bank groups (public, private and foreign banks) separately and capture competitive effects of different ownership of banks.

Although all banks are important in terms of financial development and their contribution to poverty reduction and economic growth (Levine, 1997), differentiation across different bank groups is useful because Indian public banks are guided by national policy priorities, whereas private banks have somewhat more freedom to pursue their own markets. International banks, in contrast, are predominantly located in metropolitan cities and we wanted to examine whether their behaviour is different from domestic banks. Nonetheless, despite these differences all bank groups (including foreign banks with more than 20 branches) should meet priority sector lending targets of $40 \%$ of net bank credit (RBI, 2020a). ${ }^{2}$ Lately, the crucial role played by public banks in contributing to financial stability especially in crisis (e.g. 2007-08 global financial crisis) has been well acknowledged (Andrianova, 2012; Arora, 2017; Panizza, 2012; Yeyati et al., 2007). ${ }^{3}$ Furthermore, the years covered in our study show different phases of India's economic development since the 1991 reforms. Also, following existing literature (Ayyagari et al., 2020) our index combines both financial depth (captured by credit/GDP ratio) and outreach indicators (proxied by population covered per bank branch). Finally, our study has implications not just for India but also for other similar large emerging economies with sub-national variations in banking development and existing regional inequalities.

Following this Introduction, section 2 briefly presents related literature. Section 3 lays out stylised facts on India's financial sector. Section 4 provides methodology and outlines choice of indicators. Section 5 presents banking development indices for public, private and foreign bank groups and discusses major findings. Finally, in section 6 conclusions and implications are discussed.

\section{Literature review}

On spatial and geographical inequalities, Kanbur and Venables (2005) note 'spatial inequality is a dimension of overall inequality, but it has added significance when spatial and regional divisions align with political and ethnic tensions to undermine social and political stability'. Prager and Thisse (2012) observe, ' $\ldots$ while it is true that the importance of proximity to natural resources has declined considerably...this does not mean that distance and location have disappeared from economic life. Quite the contrary, economic geography indicates that new forces, hitherto outweighed by natural factors, are shaping an economic landscape that, with its many barriers and inequalities,

\footnotetext{
${ }^{2}$ Priority sector includes agriculture, micro, small and medium enterprises, export credit, education, housing, social infrastructure and others (RBI, 2020a).

${ }^{3}$ Even in post-Covid-19 economic recovery public banks are expected to play an important role (IMF, 2020).
} 
is anything but flat'. In the early literature, Robock (1960) had cautioned 'Increasing attention... is now being paid to the related problem of regional economic disparities within a country'.

Earliest studies for instance, Williamson (1965) explained that regional disparities rise in the early stages of development and weaken in later stages. Empirically, several studies such as Démurger (2001) and Kanbur and Zhang (2005) for China; Esmara (1975) for Indonesia; Azzoni (2001) for Brazil; Bonet (2006) for Columbia; Yamamoto (2007) and Kim (2009) for the USA have examined regional disparities. These studies have analysed regional disparities using different methodologies, time periods and identified different factors potentially causing disparities. For instance, Kanbur and Zhang (2005) identify industrial output, degree of decentralisation and degree of openness as the factors responsible for regional disparities in China. Bonet (2006) argues that poorly designed decentralisation policies led to increase in regional disparities in Columbia. Institutional factors also could lead to increase in income inequality as Holcombe and Boudreaux (2016) concluded in their study on market institutions. Kim (2017) assigned divergence in legal and political institutions in explaining differences in the level of economic development in Virginia and Massachusetts in the USA.

Similar to large countries, even small countries can have significant regional inequalities as several papers in Felsenstein and Portnov (2005) argued. Within the United Kingdom, for example, significant regional variations exist with a clear North-South divergence visible. Such disparities, whether in large or small countries, can concentrate poverty in certain regions, skew intra-national migration patterns, create the grounds for resource-based and inequality-based conflicts and militancy and pose threats to national security in general. In the context of Sustainable Development Goals (SDGs), eliminating extreme poverty and hunger, reducing other forms of poverty and promoting inclusive and sustainable human settlements are national policy priorities (SDGs 5 and 10). Not much literature, however, exists on the role of financial sector in escalating or reducing regional disparities.

Theoretically, well-developed financial systems can promote economic growth, remove financing constraints for firms, reduce poverty and provide new opportunities (Jalilian and Kirkpatrick, 2005; Levine, 1997). Less developed financial systems, on the contrary, lead to entrenching of inequality, loss of opportunities to the poor, less investment in enterprise growth and human capital development (Arora, 2012; Claessens and Perotti, 2007). Economic history suggests that due to path dependence and long-term nature of institutional evolution, in many former colonies, the present-day institutions may still be affected by the colonial and extractive institutional architecture notwithstanding several decades of policy interventions after Independence (Acemoglu and Robinson, 2012; Greif, 2006).

Empirically, among the few studies Peng et al. (2010) examined regional finance as the cause of regional disparities in China. Zou and He (2018) employing data on 282 Chinese cities investigated the relationship between economic disparity and financial sector. Sharma (2008) investigated whether regional disparities in India are due to immobility of capital. Findings show that high returns to capital exist in low industrial districts. Regional inequality, therefore, could be reduced if financial sector is developed further and capital is made more mobile. Rajesh Raj et al. (2014) explore whether inequalities in banking services explain disparities in firm start-ups in the informal sector in India. Results show that although availability of local bank branches had a positive impact on informal firms, the effect was more pronounced for the large firms within the sector. Kumar (2013) in the Indian context showed branch network having a positive impact on financial inclusion. Similarly, Zeng (2016) examined the impact of capital immobility on regional incomes and inequality. Data (from New World Wealth 2018) on world's top 15 wealthiest cities (including New York, London, Paris and Mumbai) also show that almost all of them are financial centres indicating that wealth creation and financial services may be spatially associated (due to agglomeration economies). Younas (2009), although not focused on within country inequality, notes that institutional factors such as strength of the legal system, investment risk and democratic accountability impacts capital mobility in developing countries.

Above indicates that unequal financial sector has profound implications for the rest of the economy and an inclusive financial development may provide more opportunities and reduce regional inequalities. Improved access to financial services and products for the households also promotes financial 
development, contributes to economic growth, reduces income inequality, poverty and has positive effect on household incomes (Beck \& De La Torre, 2007; Demirguc-Kunt et al., 2017). Recent years have witnessed considerable emphasis on financial inclusion by several developing and developed economies. Yet, not much is known on the level of financial development at the sub-national level.

In the Indian context, several studies examined differences in states' economic performance in prereform and post-reform periods and observed a widening of regional disparities especially since the 1990s. ${ }^{4}$ Joumard et al. (2017) also observed increasing inter-state and rural-urban inequalities. Poverty in all dimensions is also higher in the rural areas as the UNDP Multidimensional Poverty Index noted that $69 \%$ of rural poor households are multidimensionally poor compared to $31 \%$ in the urban areas (OPHI, 2017). Chancel and Piketty (2017) observed that Indian income inequality (marked decline in the early 1940s and strong reduction in top income shares in 1950-1970s) registered a significant increase from 1980s onwards. These trends are consistent with growth episodes in other emerging economies such as Brazil and China, both of which experienced worsening regional inequalities as their economies began to grow after the mid-1990s (Anand et al., 2021).

Disparities also exist in the availability of infrastructure facilities and human development. Per capita electricity consumption, for instance, was only $133.6 \mathrm{~kW}$ hours in Bihar, a less developed state compared to $1,799.01 \mathrm{~kW}$ hours in Punjab in 2011. Other infrastructure facilities such as road density and teledensity (number of telephone landline connections per 1,000 population) are also low in less developed states compared to more developed and prosperous states. Of course, with the advent of mobile phones, landlines are becoming less important, but it may still indicate some degree of inequality especially concerning enterprises and firms. Among development indicators, infant mortality rates vary from 12 per 1,000 live births (Kerala) to 52 per 1,000 live births (Madhya Pradesh). A composite infrastructure index covering both dimensions - physical infrastructure (electricity consumption, road density and teledensity) and social infrastructure (human development and quality of life indicators) for 2011-12 once again confirms considerable differences across states (Figure 1)..$^{5}$

Another useful index at the sub-national level is Social Progress Index (2017) (SPI) which captures social progress or citizens' experience in three dimensions - basic human needs (includes nutrition, basic medical care, water and sanitation, shelter and personal safety); well-being (includes education, access to information, health care and environmental quality) and opportunity (captures citizens personal rights, personal freedom and choice, inclusion of different groups and access to advanced education). This index covers outcome indicators and also reflects institutional quality at the state level (Nirola and Sahu, 2019). In 2017 the index scores ranged from high of 68.09 (Kerala) to a low of 44.89 (Bihar). Overall, it showed that although all states have made headway in terms of social progress over the years, considerable differences still persist. An interesting finding is that the states which have performed well economically have not necessarily performed well in social progress (for instance Maharashtra, Gujarat and Karnataka) and reverse in the states such as Kerala which scored highest (68.09) despite low-economic achievements.

\section{Stylised facts on Indian financial sector}

Indian financial sector is largely dominated by commercial banks comprising public, private and foreign banks. As of March 2016, there were 27 public banks, 21 private banks, 43 foreign banks and 56

\footnotetext{
${ }^{4}$ Ahluwalia (2002); Kurian (2000); Rao et al. (1999); Sachs et al. (2002). Although a number of studies noted divergence across the states (Rao et al., 1999; Sachs et al., 2002), some have shown evidence of absolute convergence (Cashin and Sahay, 1996; Dholakia, 1994). Some studies also noted evidence of conditional convergence (Cherodian and Thirlwall, 2015; Purfield, 2006).

${ }^{5}$ Although the methodology followed is similar to the used in the construction of banking development indices in section 3.1 , we reversed the values in minimum and maximum territories to reflect negativity of some social indicators, for instance infant mortality rate where minimum reflects positive trend and maximum reverse.
} 


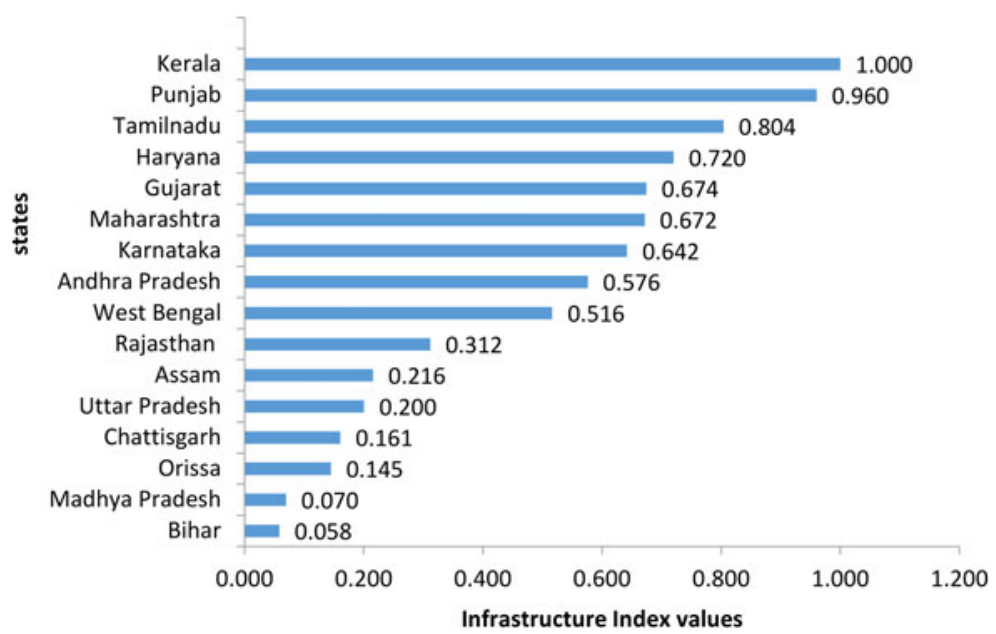

Figure 1. Composite infrastructure index of states.

RRBs. ${ }^{6}$ The government continues to maintain more than the statutory minimum shareholding of $51 \%$ in all public banks (RBI, 2016).

Besides commercial banks, hosts of other financial intermediaries co-exist e.g. cooperative banks, small payment banks, development banks and non-banking financial companies (NBFC). Total number of NBFCs registered with RBI in March 2016 was 11,682 of which 202 were deposit-taking and 11,480 non-deposit accepting. In 2014-15, NBFC assets (deposit and non-deposit taking)/GDP ratio was only $12.9 \%$ compared to $96.4 \%$ of banking sector (Arora and Zhang, 2019). Credit intensity measured by NBFCs credit/GDP ratio was $11.6 \%$ in $2019-20$ compared to $50.7 \%$ of non-food credit banks/GDP ratio (RBI, 2020b). Of total non-deposit accepting NBFCs, 220 are systemically important, i.e. those with asset size greater than Rs 5 billion. Total assets of deposit accepting NBFCs was Rs 2.4 trillion in 2016 forming $14 \%$ of total NBFC assets whereas those of systemically important NBFCs were Rs 14.8 trillion. Despite their smaller size compared to banks, NBFCs have played a crucial role in providing financial access to rural, agricultural and small borrowers (Arora and Zhang, 2019; Mohan and Ray, 2017). Major factors behind the rise of NBFCs in the recent years include ongoing financial sector reforms allowing entry to new entrants; unmet demand from small and rural borrowers; risk averseness of commercial banks following high prevalence of non-performing assets.

Development banks (almost all government owned), which played a significant role prior to 1990s in India, have been largely closed or merged with their parent institutions in recent years. Total disbursements (mostly private sector) by development banks as proportion of gross fixed capital formation in the manufacturing sector rose from $10 \%$ in $1970-71$ to $36 \%$ in $1990-91$ and further to $49 \%$ in 2000-01 however, declined sharply to just 6\% in 2005-06 (Nayyar, 2015). Only three development banks (mainly refinancing institutions) still exist - National Bank for Agriculture \& Rural Bank, National Housing Bank and Small Industries Development Bank of India. Furthermore, several urban and rural cooperative banks exist, however these are very much localised. In this study we, therefore, focus on commercial banks as they are the major financial intermediaries and are well spread out across the country.

Tables 1-3 show disparities in the Indian banking sector. For analytical brevity, we use the terms leading and lagging regions, where leading have income above the national income average, whereas lagging have income below that threshold (Appendix A). Table 1 reveals disparities in

\footnotetext{
${ }^{6}$ As on March 2021, the Indian banking sector consists of 12 public banks (post-merger and consolidation of public banks), 22 private banks, 46 foreign banks, 10 small finance banks, 2 payment banks and 43 RRBs.
} 
Table 1. Bank branch density in India

\begin{tabular}{lcccc}
\hline $\begin{array}{l}\text { Stages of } \\
\text { development }\end{array}$ & $\begin{array}{c}\text { Average per capita } \\
\text { income (Rs) }\end{array}$ & $\begin{array}{c}\text { Average population per } \\
\text { branch (in 000s) }\end{array}$ & $\begin{array}{c}\text { Average no. of } \\
\text { bank branches }\end{array}$ & $\begin{array}{c}\text { Average no. of } \\
\text { branches per sq. km }\end{array}$ \\
\hline Leading & 42,033 & 3 & 4 & 5 \\
\hline Lagging & 23,029 & 11.2 & 4,053 & 0.04 \\
\hline Mean & 32,531 & 19.1 & 2,512 & 0.02 \\
\hline SD & $13,437.86$ & 15.15 & $3,282.5$ & 0.03 \\
\hline CV (\%) & 41.3 & 5.59 & $1,089.65$ & 0.01 \\
\hline
\end{tabular}

Source: Computed by authors. Derived from Reserve Bank of India Publications and CSO data on state Gross Domestic Product. Note: Excludes union territories.

Table 2. Bank services across regions

\begin{tabular}{lccccc}
\hline $\begin{array}{l}\text { Region/stages of } \\
\text { development }\end{array}$ & $\begin{array}{c}\text { Average income } \\
\text { per capita (Rs) }\end{array}$ & $\begin{array}{c}\text { Deposits/ } \\
\text { NDP (\%) }\end{array}$ & $\begin{array}{c}\text { Credit/ } \\
\text { NDP (\%) }\end{array}$ & $\begin{array}{c}\text { Deposit per } \\
\text { capita (Rs) }\end{array}$ & $\begin{array}{c}\text { Credit per } \\
\text { capita (Rs) }\end{array}$ \\
\hline Leading & 2 & 3 & 4 & 5 & 6 \\
\hline Lagging & 42,033 & 138.4 & 98.5 & 40,024 & 28,849 \\
\hline Mean & 23,029 & 100.6 & 45.3 & 15,961 & 7,186 \\
\hline SD & 32,531 & 119.5 & 71.9 & $27,992.5$ & $18,017.5$ \\
\hline CV (\%) & $13,437.86$ & 26.73 & 37.62 & $17,015.11$ & $15,318.05$ \\
\hline
\end{tabular}

NDP, net domestic product.

Source: Computed by authors. Derived from Reserve Bank of India Publications and CSO data on state Gross Domestic Product. Note: Excludes union territories.

Table 3. Public, private and foreign provision of bank services across regions

\begin{tabular}{lccccccc}
\hline Region & $\begin{array}{c}\text { Average } \\
\text { income per } \\
\text { capita (Rs) }\end{array}$ & $\begin{array}{c}\text { Credit by } \\
\text { public } \\
\text { banks/NDP }\end{array}$ & $\begin{array}{c}\text { Credit by } \\
\text { private } \\
\text { banks/NDP }\end{array}$ & $\begin{array}{c}\text { Credit by } \\
\text { foreign } \\
\text { banks/NDP }\end{array}$ & $\begin{array}{c}\text { Deposit in } \\
\text { public } \\
\text { banks/NDP }\end{array}$ & $\begin{array}{c}\text { Deposit in } \\
\text { private } \\
\text { banks/NDP }\end{array}$ & $\begin{array}{c}\text { Deposit in } \\
\text { Foreign } \\
\text { Banks/NDP }\end{array}$ \\
\hline Leading & 42,033 & 3 & 4 & 5 & 6 & 7 & 8 \\
\hline Lagging & 23,029 & 0.74 & 0.17 & 0.05 & 1.05 & 0.25 & 0.06 \\
\hline Mean & $35,420.83$ & 0.35 & 0.06 & 0.00 & 0.78 & 0.13 & 0.01 \\
\hline SD & $15,043.76$ & 1.01 & 0.08 & 180.84 & 0.30 & 0.15 & 0.03 \\
\hline CV $(\%)$ & 42.5 & 112.3 & 80.3 & 147.3 & 28.7 & 72.4 & 1.05 \\
\hline
\end{tabular}

NDP, net domestic product.

Source: Computed by authors. Derived from Reserve Bank of India Publications and CSO data on state Gross Domestic Product. Note: Excludes union territories.

bank branch density across the leading and lagging regions. As there is considerable disparity in the economic development of states, deposits and credit per capita are significantly higher in the leading regions compared to lagging ones (Table 2). Furthermore, almost all bank groups (public, private and foreign) are concentrated in terms of deposit and credit, more in the leading and developed regions (Table 3). 


\section{Methodology and data specification}

Many studies have used indicators such as M3/GDP (broad money or liquid liabilities) or private credit/GDP to proximate financial development. In recent studies, Arcand et al. (2012) use credit/ GDP ratio, whereas Dabla-Norris and Srivisal (2013) employ private credit/GDP from banks and other financial institutions to investigate impact of macroeconomic volatility. Ang (2010) to represent overall financial sector development considered claims on private sector/GDP; M3/GDP; share of commercial bank assets in the sum of commercial and central bank assets.

Financial development is, however, a multidimensional concept encompassing different dimensions e.g. outreach, size, depth, stability and access to finance (Čihák et al., 2012). Lone or a couple of measures cannot capture the complexity of the financial system (Svirydzenka, 2016). As Creane et al. (2003) observed:

Financial sector development is a multifaceted concept, encompassing not only monetary aggregates and interest rates (or rates of return) but also financial openness, regulation and supervision, technological advances, degree of competition, and institutional capacity such as the strength of creditor rights.

This multidimensionality of financial development is also captured by Svirydzenka (2016) who defined financial development as:

combination of depth (size and liquidity of markets), access (ability of individuals and companies to access financial services), and efficiency (ability of institutions to provide financial services at low cost and with sustainable revenues, and the level of activity of capital markets).

As single indicator is unable to capture the full extent of financial development, we build composite banking index for 25 states for 1996-2015. Following the literature, we follow similar methodology followed by UNDP in building its human development index and other UNDP indices (Arora, 2012). The detailed methodology and choice of indicators are given below.

\section{Methodology}

We denote each bank group by $D_{j}$ where $j=1 \ldots J$, and therefore, in our case $j=3$ (public, private and foreign). Each dimension consists of $n$ number of determinants which we denote by $X_{i}$, and $i=1$ to $n$. First, we compute the value $X_{i}$ for each dimension $j$ as follows:

$$
X_{i j}^{k}=\frac{X_{i j 1}^{k}-X_{i j 2}^{k}}{X_{i j 3}^{k}-X_{i j 1}^{k}}
$$

Here, the notations $X_{i j 1}^{k}, X_{i j 2}^{k}$ and $X_{i j 3}$, respectively, represent actual (1) observed value, minimum value (2) and maximum value (3) for $i$ th determinant in $j$ th dimension. The minimum and maximum values, termed as 'goalposts' (UNDP, 2009), are minimum and maximum values of each variable in different states. Now, we use simple arithmetic average as follows to determine the value for each dimension $D_{j}$. We use arithmetic average instead of geometric mean mainly because of several dimensions having values of zeros or close to zero observations in our database particularly for foreign banks. Arithmetic mean takes zeros or very low values into account implying that high values perfectly substitute for low or zero values. In contrast, geometric mean does not proceed with zero or near zero values and values are imperfect substitutes of each other (Svirydzenka, 2016):

$$
D_{j}=\frac{\sum_{i=1}^{n} X_{i j}^{k}}{n}
$$


Next, we assign equal weights (denoted by $\alpha_{j}$ for dimension $j$ to each dimension). We compute the banking development index for each bank group at the sub-national level as follows:

$$
\text { Banking sector Index }=\sum_{j=1}^{J} \alpha_{j} D_{j}
$$

There are number of missing values on both deposits and credit for foreign banks especially in the lagging states. ${ }^{7}$ This clearly indicates that foreign banks are very picky and prefer locating in developed and more prosperous regions, indulge in so-called 'cream skimming' and provide finance to selected very profitable firms (Gormley, 2010; Sarma and Prashad, 2016; Sharda et al., 2014). They consequently avoid spreading to rural or lagging regions resulting in negligible or no deposit/credit values. We have set the values to zero if no data are available. This is not ideal but in the circumstances with limited data we believe this is a reasonable compromise.

\section{Choice of indicators}

Some studies have built financial development indices at the cross-country level and national level. World Economic Forum (2012) used seven dimensions - institutional environment, business environment, financial stability, banking financial services, non-banking financial services, financial markets, financial access and constructed financial development index for 62 countries. Hong Kong SAR scored highest at 5.3 out of 7, whereas Venezuela scored lowest (2.37). India ranked 40 (3.3) out of 62 and slightly ahead of Peru, Turkey and Mexico and behind Slovak Republic and Poland.

At the cross-country level, Arora (2012) built multidimensional financial development index including dimensions - banking development; financial freedom; regulation and supervision and institutional environment. The indicators included M2/GDP, non-performing loans, interest rate spread, domestic private sector credit, value of stocks traded/GDP, number of bank branches and ATMs per 100,000 people, financial freedom from Heritage Foundation, bank capital/assets ratio, credit depth of information index and strength of legal rights index. Svirydzenka (2016) developed financial development index for 183 countries for 1980 to 2013 capturing depth, access and efficiency dimensions.

At the sub-national level, time series bank group data on many indicators usually employed in cross-country studies are not available. We have come across only one study which has attempted to construct a banking index to measure the outreach of banking services across different states of India. Pal (2009) constructed a banking index for 14 major states combining indicators on access and banking services usage to arrive at the level of banking development. Our index differs from $\mathrm{Pal}$ (2009) as it covers 25 states, includes increased number of years and unlike Pal (2009) we build separate indices for public, private and foreign banks.

As we focus on banks and different bank groups, we only consider banking indicators and construct indices for the three bank groups separately (something not done in Pal, 2009). At the sub-national level for different bank groups and years, data are only available for credit, deposit and population per bank branch. Following other studies, we, therefore, focus on above three variables (Degryse and Ongena, 2005; Jayaratne and Strahan, 1996). We do not have bank group data on other dimensions for instance, efficiency and stability of the financial system (average staff costs per branch, or non-performing assets at the state level). Nonetheless, our choice of indicators, constrained by data availability, reflects depth and outreach of banking services in different Indian states.

In this study, we have captured to some extent financial development since the initiation of economic reforms covering 1997 east Asian financial crisis, 2001 Millennium and Dot.Com bubble and 2007-08 global financial crisis. However, we do not aim to identify or isolate specific effects of each of those events.

\footnotetext{
${ }^{7}$ There is no selection bias in our data selection strategy. Data are equally available for both developed and developing states. In case of foreign banks (which form a miniscule proportion of total credit and deposits anyway) data are missing for lagging states because they avoid locating (or providing financial services) to these regions hence, data may not exist.
} 
We construct composite indices for different bank groups in 25 states considering three broad indicators - deposits; credit and population per bank branch reflecting financial system's depth and outreach. Credit indicators include per capita bank credit; credit/state output and number of credit accounts per 1,000 people. Deposit indicators are deposits/state output; deposit accounts per capita (number of deposit accounts per 1,000 people) and per capita bank deposit. Although deposits reflect public's trust in the banking system, sensitivity to interest rate, relative liquidity, resource allocation and technological innovation; provision of bank credit too demonstrates various functions performed by the financial system (Levine, 1997). Close access to bank branches also matters in credit demand and provision of credit by the banks (Jayaratne and Strahan, 1996). However, although a higher bank credit/GDP ratio indicates financial sector's depth and improved financial development, yet this focuses only on the size (quantity) of credit regardless of credit quality. Nonetheless, depth and outreach are standard indicators adopted by other studies too (Ayyagari, et al., 2020).

Our data cover the period 1996-2015 and is sourced from annual publications of RBI for banking indicators and Central Statistical Organisation for state output. Data available on credit for each bank group relate to total credit and do not distinguish between public and private credit.

\section{Results}

Bank group indices for public, private and foreign banks for each state for 1996-2008 and 2009-2015 are shown in Tables 4 and 5. ${ }^{8}$ As the aggregate banking index shows (column 6, Table 4), Maharashtra (western region) has outperformed all other states followed by Tamilnadu, Karnataka and Kerala (southern region). An interesting observation was high presence of public banks in agriculturally prosperous state, Punjab, higher even than the developed and well-banked state, Maharashtra. A rapid increase in public bank branches followed by manifold increase in deposits and credit also took place in Punjab during 1996-2008 (Kaur and Silony, 2011). However, the state has not performed well in the post-reform period and its economic growth has decelerated due to several factors such as a lack of technological breakthroughs, decline in public expenditure particularly development expenditure, low human capital development and crisis in the agricultural sector (Shergill and Kaur, 2019; Singh and Singh, 2002).

During 2009-15 as well, the top four states continue to be Maharashtra followed by three southern states Tamilnadu, Karnataka and Kerala (Table 5). Although Punjab's overall ranking remained the same as in 1996-2008, in terms of composition the proportion of public banks declined with a slight increase in private banks during this period. Overall, the position of top three and bottom three states in aggregate banking index has remained unchanged reflecting a lack of convergence across the states, lop-sidedness of regional development and persistence in regional disparities (Joumard, et al., 2017; Kumar, 2013).

An interesting finding is improvement in the ranking of some north-eastern states (Arunachal Pradesh, Tripura, Mizoram and Meghalaya) during 2009-15, although most still fall in the lagging group. Population covered per bank branch (public and private banks) declined steadily in these states showing increased government emphasis on enhancing financial inclusion (Figure 2).

Following Sarma and Pais (2011), we grouped states into four categories: those with indices value $<0.1$, low $(0.10-0.24)$, medium $(0.25-0.49)$ and high banking development values $(>0.5)$. In 1996-2008, only four states had high financial development and at least 14 states fell into low to very low banking development group (Figure 3). There were marginal changes during 2009-15 as states with high financial development declined to three instead of four earlier. The number of states, however, falling in low to very low banking development group declined to 10 as financial development improved in few states reflecting increased governmental focus on financial inclusion in the recent years.

Furthermore, banking presence is far higher in leading states compared to lagging states (Tables 6 and 7). All bank groups, including public banks, are inclined towards leading regions compared to

\footnotetext{
${ }^{8} \mathrm{We}$ also computed regional indices of banking development for public, private and foreign banks. The results are not reported here due to the lack of space and can be obtained on request.
} 
Table 4. Ranking of states in aggregate banking indices (1996-2008)

\begin{tabular}{|c|c|c|c|c|c|}
\hline \multirow[b]{2}{*}{ States } & \multicolumn{3}{|c|}{$\begin{array}{l}\text { Normalised values of indices } \\
\text { (average 1996-2008) }\end{array}$} & \multirow{2}{*}{$\begin{array}{c}\text { Aggregate banking } \\
\text { index (average } \\
\text { 1996-2008) }\end{array}$} & \multirow{2}{*}{$\begin{array}{l}\text { Ranking of states in } \\
\text { aggregate banking index } \\
\text { (average 1996-2008) }\end{array}$} \\
\hline & $\begin{array}{l}\text { Public } \\
\text { banks }\end{array}$ & $\begin{array}{c}\text { Private } \\
\text { banks }\end{array}$ & $\begin{array}{c}\text { Foreign } \\
\text { banks }\end{array}$ & & \\
\hline 1 & 2 & 3 & 4 & 5 & 6 \\
\hline Maharashtra & 0.824 & 0.748 & 1.000 & 0.857 & 1 \\
\hline Tamil Nadu & 0.676 & 0.613 & 0.537 & 0.609 & 2 \\
\hline Karnataka & 0.766 & 0.471 & 0.478 & 0.572 & 3 \\
\hline Kerala & 0.719 & 0.814 & 0.169 & 0.567 & 4 \\
\hline Punjab & 0.996 & 0.259 & 0.177 & 0.477 & 5 \\
\hline Andhra Pradesh & 0.592 & 0.325 & 0.170 & 0.362 & 8 \\
\hline Gujarat & 0.578 & 0.306 & 0.182 & 0.355 & 9 \\
\hline Haryana & 0.553 & 0.241 & 0.245 & 0.346 & 10 \\
\hline Himachal Pradesh & 0.770 & 0.167 & 0.125 & 0.354 & 11 \\
\hline Arunachal Pradesh & 0.333 & 0.141 & 0.021 & 0.165 & 18 \\
\hline$J \& K$ & 0.147 & 0.991 & 0.076 & 0.405 & 6 \\
\hline West Bengal & 0.461 & 0.234 & 0.447 & 0.381 & 7 \\
\hline Uttar Pradesh & 0.389 & 0.181 & 0.078 & 0.216 & 12 \\
\hline Rajasthan & 0.270 & 0.263 & 0.106 & 0.213 & 13 \\
\hline Madhya Pradesh & 0.404 & 0.173 & 0.052 & 0.210 & 14 \\
\hline Meghalaya & 0.438 & 0.156 & 0.023 & 0.206 & 15 \\
\hline Orissa & 0.404 & 0.127 & 0.051 & 0.194 & 16 \\
\hline Jharkhand & 0.408 & 0.149 & 0.001 & 0.186 & 17 \\
\hline Assam & 0.229 & 0.106 & 0.121 & 0.152 & 19 \\
\hline Tripura & 0.367 & 0.086 & 0.001 & 0.151 & 20 \\
\hline Chattisgarh & 0.259 & 0.157 & 0.027 & 0.148 & 21 \\
\hline Mizoram & 0.278 & 0.094 & 0.000 & 0.124 & 22 \\
\hline Bihar & 0.349 & 0.002 & 0.002 & 0.118 & 23 \\
\hline Nagaland & 0.032 & 0.142 & 0.055 & 0.076 & 24 \\
\hline Manipur & 0.000 & & 0.002 & 0.001 & 25 \\
\hline Mean & 0.416 & 0.188 & 0.116 & 0.238 & \\
\hline SD & 0.256 & 0.276 & 0.224 & 0.199 & \\
\hline CV & 61.5 & 146.7 & 192.6 & 83.7 & \\
\hline
\end{tabular}

Source: Computed by authors.

lagging. These trends prevail in both time periods. ${ }^{9}$ This finding is especially surprising considering public banks are viewed as harbingers of economic development and overcome problems of market

\footnotetext{
${ }^{9}$ Other studies have also shown that, unlike common perception, public banks like private banks prefer locating their branches in high-income developed areas (Zhang et al., 2021).
} 
Table 5. Ranking of states in aggregate banking indices (2009-15)

\begin{tabular}{|c|c|c|c|c|c|c|}
\hline \multirow[b]{2}{*}{ States } & \multicolumn{3}{|c|}{$\begin{array}{l}\text { Normalised values of indices } \\
\quad \text { (average 2009-2015) }\end{array}$} & \multirow{2}{*}{$\begin{array}{c}\text { Aggregate } \\
\text { banking index } \\
\text { (avg. 2009-2015) }\end{array}$} & \multicolumn{2}{|c|}{$\begin{array}{l}\text { Ranking of states in } \\
\text { aggregate banking } \\
\text { index (avg.) }\end{array}$} \\
\hline & $\begin{array}{l}\text { Public } \\
\text { banks }\end{array}$ & $\begin{array}{c}\text { Private } \\
\text { banks }\end{array}$ & $\begin{array}{c}\text { Foreign } \\
\text { banks }\end{array}$ & & 1996-08 & 2009-15 \\
\hline 1 & 2 & 3 & 4 & 5 & 6 & 7 \\
\hline Maharashtra & 1.000 & 0.994 & 1.000 & 0.998 & 1 & 1 \\
\hline Tamil Nadu & 0.769 & 0.676 & 0.568 & 0.671 & 2 & 2 \\
\hline Karnataka & 0.709 & 0.460 & 0.568 & 0.579 & 3 & 3 \\
\hline Kerala & 0.650 & 0.643 & 0.152 & 0.482 & 4 & 4 \\
\hline Punjab & 0.842 & 0.333 & 0.148 & 0.441 & 8 & 5 \\
\hline Andhra Pradesh & 0.848 & 0.373 & 0.207 & 0.476 & 5 & 8 \\
\hline Gujarat & 0.489 & 0.333 & 0.179 & 0.334 & 11 & 9 \\
\hline Haryana & 0.555 & 0.373 & 0.256 & 0.395 & 10 & 10 \\
\hline Himachal Pradesh & 0.708 & 0.180 & & 0.444 & 7 & 11 \\
\hline Arunachal Pradesh & 0.378 & 0.135 & & 0.256 & 15 & 18 \\
\hline$J \& K$ & 0.020 & 0.914 & & 0.467 & 6 & 6 \\
\hline West Bengal & 0.630 & 0.305 & 0.294 & 0.410 & 9 & 7 \\
\hline Uttar Pradesh & 0.321 & 0.140 & 0.111 & 0.191 & 20 & 12 \\
\hline Rajasthan & 0.249 & 0.241 & 0.119 & 0.203 & 18 & 13 \\
\hline Madhya Pradesh & 0.315 & 0.170 & 0.102 & 0.196 & 19 & 14 \\
\hline Meghalaya & 0.367 & 0.176 & & 0.272 & 12 & 15 \\
\hline Orissa & 0.422 & 0.197 & 0.112 & 0.244 & 16 & 16 \\
\hline Jharkhand & 0.320 & 0.147 & & 0.234 & 17 & 17 \\
\hline Assam & 0.214 & 0.138 & 0.202 & 0.185 & 21 & 19 \\
\hline Tripura & 0.398 & 0.128 & & 0.263 & 13 & 20 \\
\hline Chattisgarh & 0.262 & 0.171 & 0.079 & 0.171 & 22 & 21 \\
\hline Mizoram & 0.351 & 0.174 & & 0.262 & 14 & 22 \\
\hline Bihar & 0.172 & 0.000 & 0.052 & 0.075 & 24 & 23 \\
\hline Nagaland & 0.104 & 0.179 & & 0.141 & 23 & 24 \\
\hline Manipur & 0.011 & 0.114 & & 0.063 & 25 & 25 \\
\hline Mean & 0.44 & 0.31 & 0.26 & 0.34 & & \\
\hline SD & 0.27 & 0.25 & 0.25 & 0.21 & & \\
\hline CV & 60.21 & 81.72 & 96.54 & 61.25 & & \\
\hline
\end{tabular}

Source: Computed by authors.

failure in financial sector and finance socially valuable projects in less developed regions and rural areas (Yeyati et al., 2005). Prior to 1991, Indian public banks have played a significant role in nationwide banking spread, reduction in rural poverty and increase in rural output (Burgess \& Pande, 2005; Arora, 2017). In the post-reform period after 1991, there is evidence of public banks having reduced 


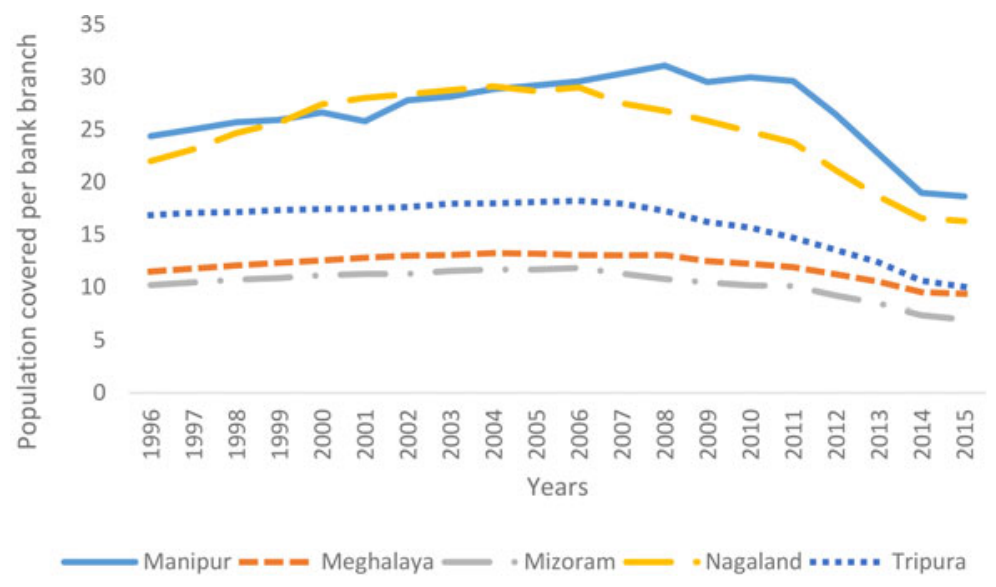

Figure 2. Population covered per bank branch in selected north-Eastern states.

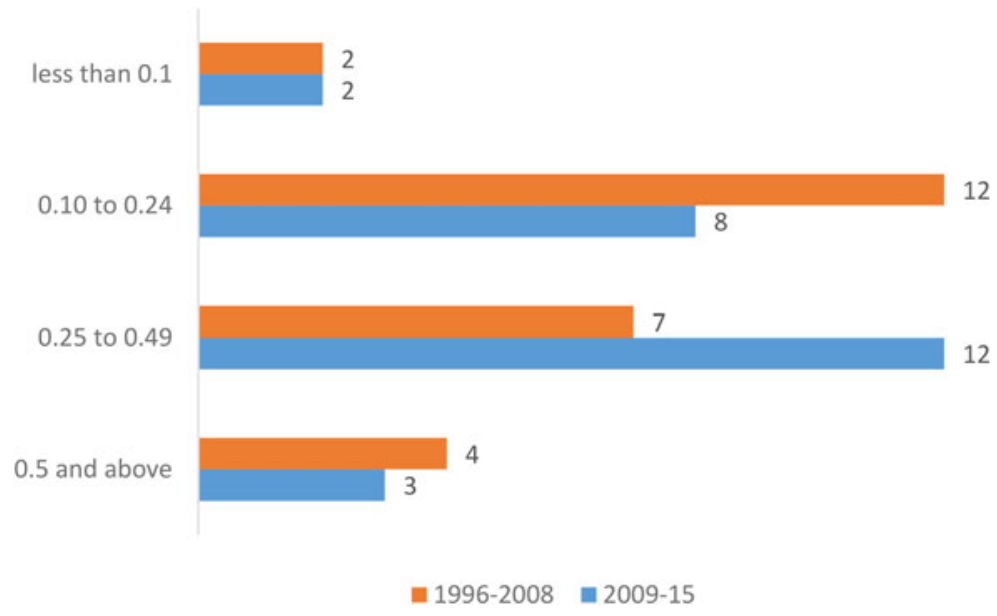

Figure 3. Banking development across the states.

their presence in lagging states through rationalisation of bank branches including rural branches and fall in credit (Kohli, 1999; Narayana, 2000; Shete, 2002). ${ }^{10}$

We also examined whether public banks could be crowding out private and foreign banks, and whether that would have an impact on states banking index rankings. The rankings excluding (and including) public banks are shown in Tables 8 and 9.

Some interesting observations from above exercise are: ranking of top end and bottom end states remains nearly the same in both rankings. However, some states - Punjab, Andhra Pradesh, Uttar Pradesh and Tripura - slip in rankings excluding PSBs showing the higher presence of public banks in these states. In contrast, some states (Jammu \& Kashmir, Rajasthan, Assam and Nagaland) have jumped in rankings excluding public banks.

\footnotetext{
${ }^{10}$ Another development in 1991 was the discontinuation of branch licensing policy implemented during the years 1977 to 1990 which required banks to open new bank branches only when they set up four new bank branches in unbanked locations (mainly rural and semi-urban areas).
} 
Table 6. Breakdown of banking indices - leading and lagging states 1996-2008

\begin{tabular}{|c|c|c|c|c|c|c|}
\hline \multirow[b]{2}{*}{ Year } & \multicolumn{2}{|c|}{ Public banks } & \multicolumn{2}{|c|}{ Private banks } & \multicolumn{2}{|c|}{ Foreign banks } \\
\hline & Leading & Lagging & Leading & Lagging & Leading & Lagging \\
\hline 1 & 2 & 3 & 4 & 5 & 6 & 7 \\
\hline 1996 & 0.658 & 0.315 & 0.378 & 0.219 & 0.276 & 0.100 \\
\hline 1997 & 0.625 & 0.305 & 0.410 & 0.219 & 0.306 & 0.102 \\
\hline 1998 & 0.661 & 0.311 & 0.336 & 0.227 & 0.368 & 0.127 \\
\hline 1999 & 0.645 & 0.274 & 0.503 & 0.238 & 0.308 & 0.192 \\
\hline 2000 & 0.643 & 0.287 & 0.395 & 0.225 & 0.300 & 0.118 \\
\hline 2001 & 0.639 & 0.260 & 0.363 & 0.202 & 0.341 & 0.156 \\
\hline 2002 & 0.627 & 0.278 & 0.420 & 0.192 & 0.265 & 0.096 \\
\hline 2003 & 0.665 & 0.298 & 0.392 & 0.192 & 0.345 & 0.093 \\
\hline 2004 & 0.686 & 0.296 & 0.421 & 0.199 & 0.383 & 0.088 \\
\hline 2005 & 0.731 & 0.325 & 0.455 & 0.222 & 0.390 & 0.131 \\
\hline 2006 & 0.751 & 0.310 & 0.425 & 0.202 & 0.395 & 0.105 \\
\hline 2007 & 0.748 & 0.285 & 0.451 & 0.209 & 0.355 & 0.082 \\
\hline 2008 & 0.773 & 0.277 & 0.472 & 0.220 & 0.316 & 0.067 \\
\hline Mean & 0.681 & 0.294 & 0.417 & 0.213 & 0.334 & 0.112 \\
\hline SD & 0.052 & 0.019 & 0.046 & 0.014 & 0.043 & 0.033 \\
\hline CV (\%) & 7.6 & 6.5 & 11.0 & 6.8 & 12.8 & 29.8 \\
\hline
\end{tabular}

Source: Authors' calculations.

Table 7. Breakdown of banking indices - leading and lagging states 2009-15

\begin{tabular}{|c|c|c|c|c|c|c|}
\hline \multirow[b]{2}{*}{ Year } & \multicolumn{2}{|c|}{ Public banks } & \multicolumn{2}{|c|}{ Private banks } & \multicolumn{2}{|c|}{ Foreign banks } \\
\hline & Leading & Lagging & Leading & Lagging & Leading & Lagging \\
\hline 2009 & 0.645 & 0.245 & 0.401 & 0.204 & 0.393 & 0.115 \\
\hline 2010 & 0.712 & 0.285 & 0.429 & 0.204 & 0.303 & 0.066 \\
\hline 2011 & 0.700 & 0.288 & 0.435 & 0.202 & 0.409 & 0.132 \\
\hline 2012 & 0.720 & 0.295 & 0.457 & 0.211 & 0.405 & 0.129 \\
\hline 2013 & 0.707 & 0.264 & 0.482 & 0.223 & 0.398 & 0.136 \\
\hline 2014 & 0.710 & 0.262 & 0.482 & 0.225 & 0.404 & 0.131 \\
\hline 2015 & 0.669 & 0.302 & 0.464 & 0.222 & 0.381 & 0.228 \\
\hline Mean & 0.695 & 0.277 & 0.450 & 0.213 & 0.385 & 0.134 \\
\hline SD & 0.027 & 0.021 & 0.030 & 0.010 & 0.037 & 0.048 \\
\hline CV & 3.95 & 7.46 & 6.67 & 4.73 & 9.68 & 35.79 \\
\hline
\end{tabular}

Source: Authors' calculations.

As mentioned elsewhere, some economically well-performing states had not performed well in the SPI. For instance, a developed state - Maharashtra, which tops in the banking development index in 2015 - slips to 7th rank in the SPI. Quite the reverse, Mizoram (north-eastern state) ranking 12th in 
Table 8. Ranking of states excluding/including public banks (average 1996-2008)

\begin{tabular}{|c|c|c|c|}
\hline \multicolumn{2}{|c|}{ Ranking of states excluding PSBs } & \multicolumn{2}{|c|}{ Ranking of states including PSBs } \\
\hline States & Ranking & States & Ranking \\
\hline Maharashtra & $1(0)$ & Maharashtra & 1 \\
\hline Tamilnadu & $2(0)$ & Tamil Nadu & 2 \\
\hline Jammu \& Kashmir & $3(+3)$ & Karnataka & 3 \\
\hline Kerala & $4(0)$ & Kerala & 4 \\
\hline Karnataka & $5(-2)$ & Punjab & 5 \\
\hline West Bengal & $6(+1)$ & Jammu \& Kashmir & 6 \\
\hline Andhra Pradesh & $7(+1)$ & West Bengal & 7 \\
\hline Gujarat & $8(+1)$ & Andhra Pradesh & 8 \\
\hline Haryana & $9(+1)$ & Gujarat & 9 \\
\hline Punjab & $10(-4)$ & Haryana & 10 \\
\hline Rajasthan & $11(+2)$ & Himachal Pradesh & 11 \\
\hline Meghalaya & $12(+3)$ & Uttar Pradesh & 12 \\
\hline Himachal Pradesh & $13(-2)$ & Rajasthan & 13 \\
\hline Nagaland & $14(+10)$ & Madhya Pradesh & 14 \\
\hline Uttar Pradesh & $15(-3)$ & Meghalaya & 15 \\
\hline Arunachal Pradesh & $16(+2)$ & Odishha & 16 \\
\hline Madhya Pradesh & $17(-3)$ & Jharkhand & 17 \\
\hline Assam & $18(+1)$ & Arunachal Pradesh & 18 \\
\hline Jharkhand & $19(-2)$ & Assam & 19 \\
\hline Chattisgarh & $20(+1)$ & Tripura & 20 \\
\hline Odissha & $21(-5)$ & Chattisgarh & 21 \\
\hline Mizoram & $22(0)$ & Mizoram & 22 \\
\hline Tripura & $23(-3)$ & Bihar & 23 \\
\hline Bihar & $24(-1)$ & Nagaland & 24 \\
\hline Manipur & $25(0)$ & Manipur & 25 \\
\hline
\end{tabular}

Source: Authors' calculations.

Note: Figures in brackets show slippages $(-)$ and gains $(+)$ compared to rankings including PSBs.

financial development, scores much higher at 4 in social progress rankings. Overall, a positive correlation (0.53) exists between the banking development index and SPI. It may be worth mentioning that our objective is not to examine causality, rather we aim only to measure and understand states financial development (and their differences).

The divergence in banking development between leading and lagging regions has in fact, increased over the years, although it has slightly narrowed from 2014 onwards and is evident across all bank groups (Figures $4 \mathrm{a}$ and $4 \mathrm{~b}$ ).

Per capita credit has been much higher to leading regions. Banks also invest in state government securities and including credit indicates total flow of funds to states. Once again, the leading states have retained their position in terms of these investments. Another indicator to examine diverse flow of funds across the states is credit-deposit ratio ( $/ \mathrm{D}$ ratio). The concept indicates the 'credit 
Table 9. Ranking of states excluding/including public banks (average 2009-15)

\begin{tabular}{|c|c|c|c|}
\hline \multicolumn{2}{|c|}{ Ranking of states excluding PSBs } & \multicolumn{2}{|c|}{ Ranking of states including PSBs } \\
\hline States & Ranking & States & Ranking \\
\hline Maharashtra & $1(0)$ & Maharashtra & 1 \\
\hline Jammu \& Kashmir & $2(+4)$ & Tamilnadu & 2 \\
\hline Tamilnadu & $3(-1)$ & Karnataka & 3 \\
\hline Karnataka & $4(-1)$ & Kerala & 4 \\
\hline Kerala & $5(-1)$ & $\mathrm{AP}$ & 5 \\
\hline Haryana & $6(+4)$ & $J \& K$ & 6 \\
\hline West Bengal & $7(+2)$ & $\mathrm{HP}$ & 7 \\
\hline Andhra Pradesh & $8(-3)$ & Punjab & 8 \\
\hline Gujarat & $9(+2)$ & West Bengal & 9 \\
\hline Punjab & $10(-2)$ & Haryana & 10 \\
\hline Rajasthan & $11(+7)$ & Gujarat & 11 \\
\hline Himachal Pradesh & $12(-5)$ & Meghalaya & 12 \\
\hline Nagaland & $13(+10)$ & Tripura & 13 \\
\hline Meghalaya & $14(-2)$ & Mizoram & 14 \\
\hline Mizoram & $15(-1)$ & Arunachal Pradesh & 15 \\
\hline Assam & $16(+5)$ & Orissa & 16 \\
\hline Orissa & $17(-1)$ & Jharkhand & 17 \\
\hline Jharkhand & $18(-1)$ & Rajasthan & 18 \\
\hline Madhya Pradesh & $19(0)$ & MP & 19 \\
\hline Arunachal Pradesh & $20(-5)$ & UP & 20 \\
\hline Tripura & $21(-8)$ & Assam & 21 \\
\hline Uttar Pradesh & $22(-2)$ & Chattisgarh & 22 \\
\hline Chattisgarh & $23(-1)$ & Nagaland & 23 \\
\hline Manipur & $24(+1)$ & Bihar & 24 \\
\hline Bihar & $25(-1)$ & Manipur & 25 \\
\hline
\end{tabular}

Source: Authors' calculations.

Note: Figures in brackets show slippages $(-)$ and gains $(+)$ compared to rankings including PSBs.

direction of banks and is used as a credit efficiency indicator for analyzing the role of banks in promoting productive sectors and contributing to economic growth' (RBI, 2003, 2005: 77). In 2008, the C/ $\mathrm{D}$ ratio ranged between 27.3 in Bihar, a less developed and high poverty state, and 143.3 in Tamilnadu. $^{11}$

Differences in property rights enforcement across states could be another factor which may be influencing banks in their location and lending decisions, as emphasised by De Soto (2000). ${ }^{12}$ Considerable evidence exists on secure property rights and its positive impact on per capita income, investment opportunities and efficient allocation of resources (Acemoglu et al., 2001; Field, 2007;

\footnotetext{
${ }^{11}$ This is also heavily influenced by the presence of metropolitan region. For instance, the C/D ratio of Maharashtra (excluding Mumbai) falls to $50.4 \%$, which is even lower than the ratio of less developed states, Rajasthan and Orissa.

${ }^{12} \mathrm{We}$ thank our reviewers for bringing this point to our attention.
} 


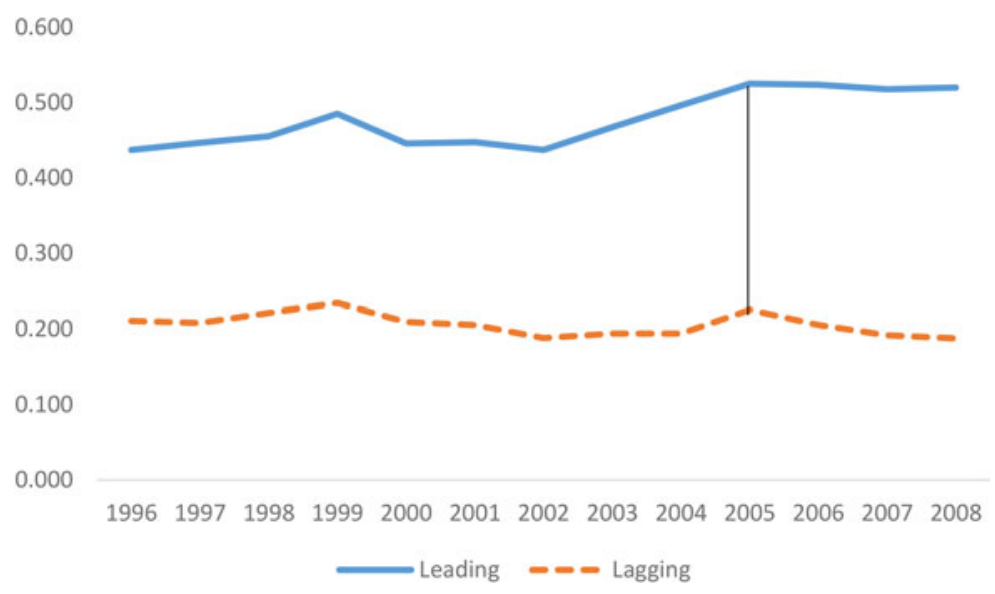

Figure 4a. Banking development in leading and lagging states during 1996-2008.

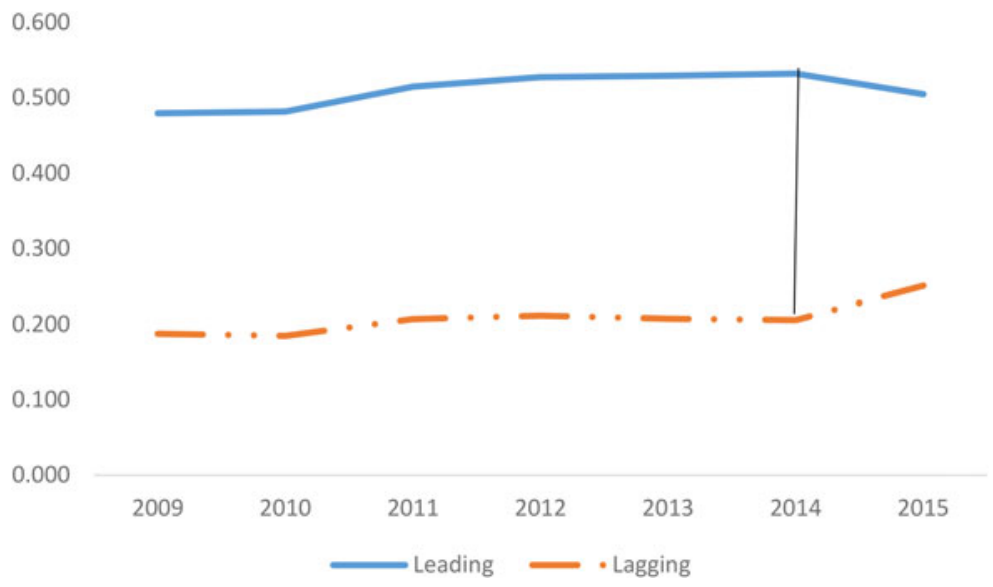

Figure 4b. Banking development in leading and lagging states during 2009-15.

Hornbeck, 2010). Furthermore, several studies have highlighted that institutional factors such as enforcement of property rights and legal rights play an important role in credit allocation (Kimura, 2011; Rao, 2020). For instance, Rao (2020) in her cross-sectional study on judicial presence (judge occupancy) and its impact on credit allocation in 195 Indian districts found that in districts with higher judicial capacity, inefficient credit allocation such as loans to defaulting firms was lower. The study also showed that 'one percentage point increase in the average prior period judge occupancy decreases outstanding loan by $0.5 \%$ '. Zhang et al. (2021) too found that region specific factors influence the location of bank branches in India.

Furthermore, land being a state subject in India, land regulations have varied from state to state (Banerjee and Iyer, 2005; Besley and Burgess, 2000; Bolhuis et al., 2020). For instance, land tenancy laws vary across India due to combination of historical land tenure systems and land being a state subject since independence (Bolhuis et al., 2020). However, despite reforms this has led to several inefficiencies and persistence of informal, insecure, short-term tenancies impacting their access to formal credit (Bolhuis et al., 2020). 


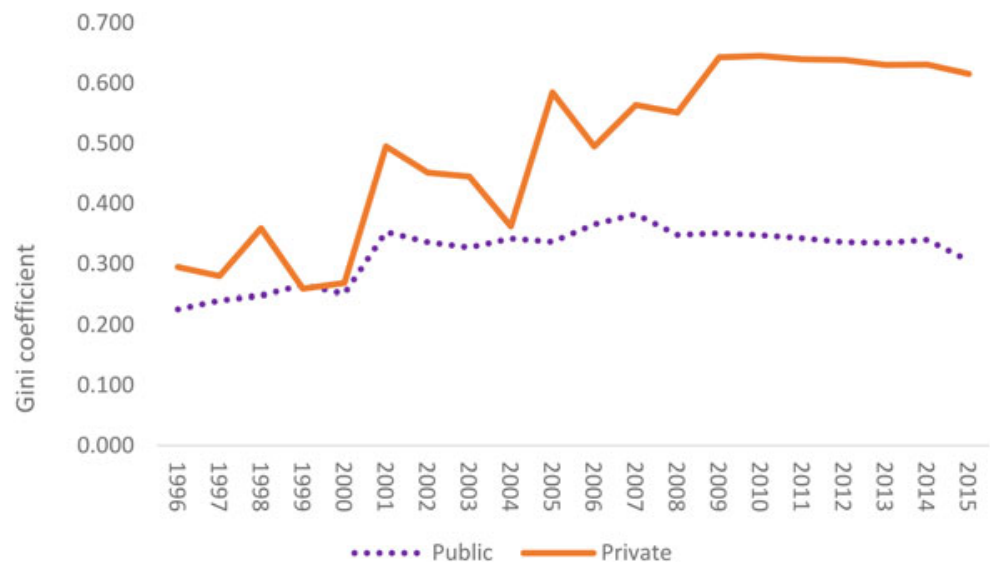

Figure 5. Disparity (Gini coefficient) in banking development across states.

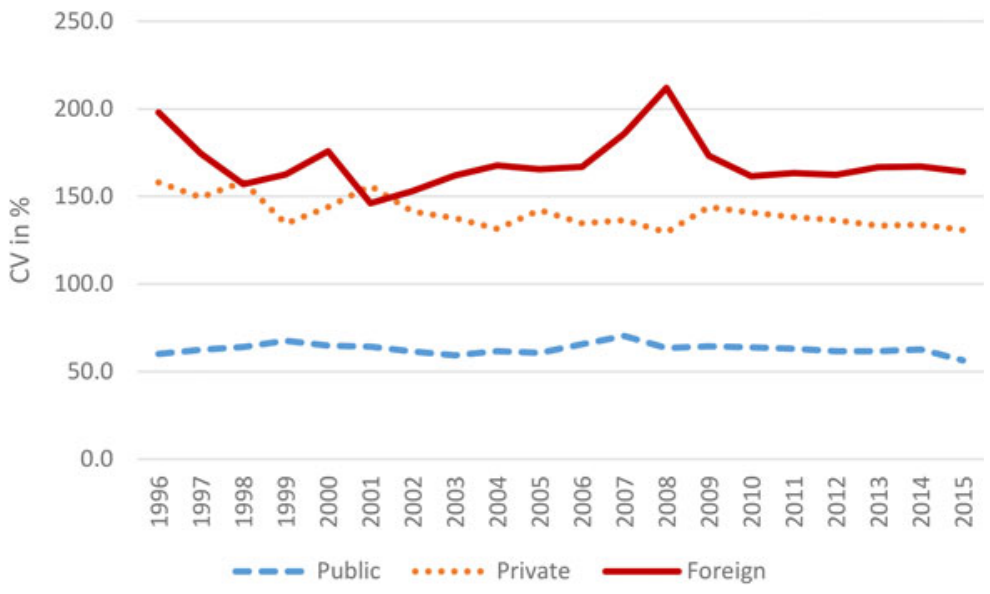

Figure 6. CV across the states.

In order to examine disparities in regional banking development even furthermore, we compute Gini coefficients for banking development indices across the states for public and private banks for 1996 to 2015 . The value of Gini lies between 0 and 1 . Zero value implies that financial development across the states is perfectly equal, whereas 1 indicates a state of perfect inequality as financial development exists only in one state. Gini coefficient measures deviations from equal distribution, with a higher value indicating more unequal distribution. The formula used to calculate Gini coefficient is:

$$
G_{f d}=\left[\frac{2}{N \sum_{i=1}^{N} f d_{i}} \sum_{i=1}^{N} i \cdot f d_{i}\right]-1-\frac{1}{N}
$$

Here, $N$ is the number of states and $f d$ is the financial development of the $i$ th state. The Gini coefficients for public and private banks so estimated are plotted in Figure 5.

We further estimated the coefficient of variation (CV), the simplest and most commonly used among various methods of dispersion. The CV in financial development across the states for 1996 to 2015 for all three bank groups is shown in Figure 6. Generally, a stable trend is observed except 


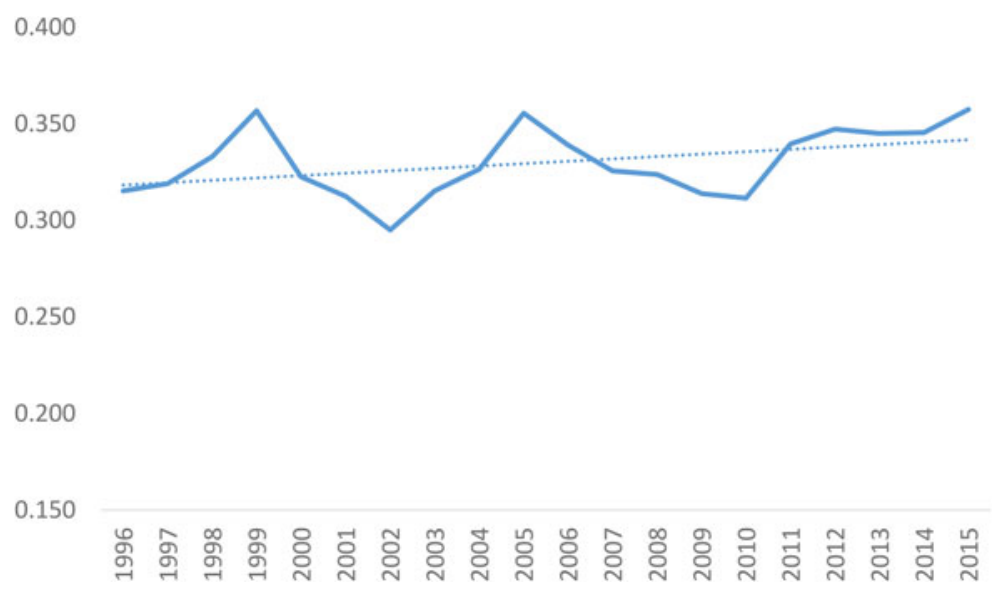

Figure 7. Banking development during 1996-2015.

for foreign banks, however, there is an evidence of a slight decline in recent period across all the bank groups. Regarding foreign banks, their entry was highly regulated until 1994 when under WTO General Agreement on Trade in Services (GATS) the licences issued to open new branches increased from initially five to 12 in 1998. The total number of foreign bank branches declined in 2003 and 2004 to 219 (from 251 in 2002) rising again to 229 in 2008 and further to 286 in 2018. The fall in the number of foreign bank branches in 2003 was mainly due to the closure of some banks and merger of Standard Chartered Grindlays Bank Ltd. with Indian branches of Standard Chartered Bank (Sharda et al., 2014). Global financial crisis of 2008 also affected the performance of both foreign and private banks as their credit declined and flight of deposits to public banks took place (Acharya and Kulkarni, 2012; Eichengreen and Gupta, 2012). As Eichengreen and Gupta (2012) note, 'deposit reallocation from the foreign banks was statistically as sharp as from the domestic private banks; and the credit growth slowdown from the foreign banks was also comparable to that of the Indian private banks'.

As Svirydzenka (2016) observes, 'financial development is not (added) linear process. Indeed, like with economic development, some countries go through stages of development, but then regress'. Overall, banking development across the Indian states has progressed (Figure 7), although it was influenced by the trend in public banks. The country's banking sector remained predominantly in the public sector with public banks accounting for $72.1 \%$ of total banking assets even as in 2014, notwithstanding the marginal decline in ownership over the years. The Government of India continues to hold more than the stipulated $51 \%$ shareholding in all the public banks, despite a decline in the stake in some of them in recent years. Even as in 2020 government shareholding in public banks ranges from 57.9 to $97.4 \%$ (RBI, 2020b). On the contrary, this period was also marked by the entry of new private banks. Although some private banks existed prior to reforms, the entry of new ones was largely initiated from 1993 as 10 new private banks were set up. In the early 2000s, two large development finance institutions were also converted into banking institutions.

\section{Conclusion}

To summarise, our study started with the research questions: how do we measure financial development at the sub-national level? How unequal is the financial development across the states, and does it vary by ownership of financial institutions? We examined the extent of disparities in financial development at the sub-national level as a step towards understanding the financial dimension of regional disparities in the Indian context. As a large emerging economy, India is particularly an interesting case 
to examine as it is not only a large federal economy with sub-national units at varying stages of development, but the ownership of its financial sector is also quite skewed and diverse.

To investigate the extent of financial deepening at the sub-national level further, our study builds composite banking development indices for public, private and foreign banks for 25 Indian states for the years 1996 to 2015 . We have four major findings. First, over the years, the position of top three and bottom three states in the aggregate banking index has remained unchanged. Second, our results show that banking development is much higher in the leading states (i.e. leading in terms of per capita income and physical and social infrastructure) compared to the lagging states and this divergence has not narrowed over the years. Third, just like other bank groups, the presence of public banks is much higher in the leading states. In another study, our research too showed that contrary to general perception, public banks consider regional and economic activity of region in locating their bank branches (Zhang et al., 2021). Finally, an interesting finding is improvement in index scores in the recent years for some states including those in the north-east reflecting some early impact of recent drive on financial inclusion. We reiterate that our objective in this study is to examine key features of sub-national financial system and not examine endogeneity. Nonetheless, the indices could be used to carry out rigorous growth regressions to test the importance of banking access to convergence within India.

Overall, our analysis on the unevenness in the spread of financial sector development in the Indian states and its association with regional endowments indicates that regional development strategies are required to improve states' economic development.

Specific policies are needed to improve financial development in lagging regions. This requires different approaches for public and private sector banks. We believe it is difficult to force foreign banks to increase their operations in lagging states considering that they also face several constraints and tighter regulations on branch expansion (Sharda et al., 2014). It is quite possible that their products are at present geared towards high-net-worth households and formal sector firms (or cream skimming). They have the potential to come up with innovative products to capture huge market in India where there is a gap for efficient and less bureaucratic form of banking, but at present it appears that foreign banks do not see themselves doing this any sooner perhaps due to complexity of state level operations and transaction entry costs. ${ }^{13}$ That does not mean the market should not be open for entry by foreign banks but just that they are unlikely to be venturing into that segment of banking. As can be anticipated, private banks appear to be more risk averse than public banks leaving them to take care of less developed regions and rural sectors. This suggests that public banks, despite their high presence in leading states (as our results showed) are nonetheless locked into a sort of low-level equilibrium trap with a primary responsibility to provide banking services in the lagging regions. The problems of information asymmetry are high in this sector increasing the possibilities of moral hazard and proportion of non-performing loans. This suggests that some important reforms are needed for lagging states to converge and for financial development to have significant impact of extreme poverty in India and thus contribute to SDGs.

Recent drive to increase financial inclusion and financial development has remained mainly supply centric and neglects demand side barriers for instance, low incomes of many households leading to low demand for formal financial services, financial illiteracy, travelling costs to the bank to conduct banking transactions and poor education in general. Although there are efforts to formalise the financial sector, overall employment in India remains dominated by unorganised sector and merely forcing people to use formal financial channels may not work unless it is accompanied by education, awareness and safeguards for small enterprises and informal sector businesses to be part of the formal financial system. The demand for working capital and huge seasonality of such enterprises and smoothing this out through appropriate products remains a huge challenge for formal financial models especially given the nature of distribution of risks and limited penetration of insurance including business

\footnotetext{
${ }^{13}$ Foreign banks face strict guidelines in setting up branches in the north-eastern states of the country (Sarma and Prashad, 2016). Also, despite relaxing of norms on wholly owned subsidiaries by RBI, no foreign bank still operates as wholly owned subsidiary in India (RBI, 2016).
} 
insurance services. Addressing these would increase demand for financial services, improve financial inclusion and increase banking development (Tulasi et al., 2017). At the same time, as our analysis showed the crucial role played by institutional factors such as differences in land systems across the states historically which has shaped and influenced economic development including access to credit of lagging states cannot be overlooked (Banerjee and Iyer, 2005; Bolhuis et al., 2020). This implies that demand alone may not be a sole barrier to accessing financial services.

As developing countries are adopting several measures to improve financial development and financial inclusion (Demirgüç-Kunt et al., 2018), national level efforts alone may not be adequate as they may fail to redress underlying inequalities at the local/regional level. More focused approach is needed at the sub-national/local levels to achieve increased financial development (Fafchamps and Schündeln, 2013). This is especially relevant for large federal economies.

Acknowledgements. We gratefully thank the three anonymous referees and editor, Prof Geoffrey Hodgson for very valuable and constructive feedback on our paper. We also acknowledge comments and feedback received from the participants of 3rd Development Economics Conference, 17-19 June 2019, University of Lincoln, Lincoln, UK; Global Inequalities: Annual Conference of Development Studies Association, University of Manchester and Annual Conference of Regional Studies Association, held at Trinity College, Dublin.

\section{References}

Acemoglu, D., S. Johnson and J. A. Robinson (2001), 'The Colonial Origins of Comparative Development: An Empirical investigation', American Economic Review, 91(5): 1369-1401.

Acemoglu, D. and J. A. Robinson (2012), Why Nations Fail: The Origins of Power, Prosperity and Poverty (1st ed.), New York: Crown.

Acharya, V. and N. Kulkarni (2012), State Ownership and Systemic Risk: Evidence from the Indian Financial Sector during 2007-09. International Growth Centre.

Ahluwalia, M. (2002), 'State Level Performance Under Economic Reforms in India', in A. O. Krueger (ed.), Economic Policy Reforms in the Indian Economy, New Delhi: Oxford University Press, pp. 91-125.

Anand P. B., Fennell, S., Comim F. (2021), 'BRICS and Emerging Economies: An Assessment', in P. B. Anand, S. Fennell and F. Comim (eds), The Handbook of BRICS and Emerging Economies, New York: Oxford University Press, pp. 3-60.

Andrianova, S. (2012), 'Public Banks and Financial stability', Economics Letters, 116(2012): 86-88.

Ang, J. B. (2010), 'Finance and Inequality: The Case of India', Southern Economic Journal, 76(3): 738-761.

Arcand, J.-L., E. Berkes and U. Panizza (2012), Too Much Finance? IMF Working Paper 12/161. Washington: International Monetary Fund (June).

Arora, R. U. (2012), 'Financial Inclusion and Human Capital in Developing Asia: The Australian Connection', Third World Quarterly, 33(1): 177-197.

Arora, R. (2017), 'Government Intervention and Financial Sector Development', in G. Gianluigi (ed.), Development Finance: Opportunities and Challenges, London: Palgrave, pp. 53-78.

Arora, R. U. and K. Wondemu (2018), 'Do Public Sector Banks Promote Regional Growth: Evidence from an Emerging Economy', Review of Urban and Regional Development Studies, 30(1): 66-87.

Arora, R. U. and Q. Zhang (2019), 'Banking in Shadows: Evidence From Emerging Economies, China and India', Australian Economic History Review, 59(1), 103-131, doi:10.1111/aehr.12167.

Atkinson, A. (2015), Inequality: What can be Done, Cambridge: Harvard University Press.

Ayyagari, M., T. Beck and M. Hoseini (2020), 'Finance, Law and Poverty: Evidence from India', Journal of Corporate Finance, 60(c): $1-25$.

Azzoni, C. R. (2001), 'Economic Growth and Regional Income Inequality in Brazil', The Annals of Regional Science, 35(1): $133-152$.

Banerjee, A. and L. Iyer (2005), 'History, Institutions, and Economic Performance: The Legacy of Colonial Land Tenure Systems in India', American Economic Review, 95(4): 1190-1213, September.

Beck, T. and A. de la Torre (2007), 'The Basic Analytics of Access to Financial Services', Financial Markets, Institutions and Instruments, 16: 79-117.

Besley, T. and R. Burgess (2000), 'Land Reform, Poverty Reduction, and Growth: Evidence from India', The Quarterly Journal of Economics, 115(2): 389-430.

Bolhuis, M., S. Rachapalli, and D. Restuccia (2020), Misallocation in Indian Agriculture, retrieved from https://www.economics.utoronto.ca/diegor/research/BRR_India_paper_v5.pdf

Bonet, J. (2006), 'Fiscal Decentralization and Regional Income Disparities: Evidence from the Colombian Experience', The Annals of Regional Science, 40(3): 661-676. 
Burgess, R. and R. Pande (2005), 'Do Rural Banks Matter? Evidence from the Indian Social Banking Experiment', The American Economic Review, 95(3): 780-795.

Cashin, P. and R. Sahay (1996), 'Regional Economic Growth and Convergence in India', Finance and Development, 33(1): 49-52.

Chancel, L. and T. Piketty (2017), 'Indian Income Inequality 1922-2015: From British Raj to Billionaire Raj', WID World Working Paper Series No. 2017/11, World Inequality Lab.

Cherodian, R. and A. P. Thirlwall (2015), 'Regional Disparities in per Capita Income in India: Convergence or Divergence?', Journal of Post Keynesian Economics, 37(3): 384-407.

Čihák, M., A. Demirgüç-Kunt, E. Feyen and R., Levine (2012), Benchmarking Financial Development Around the World. World Bank Policy Research Working Paper 6175.

Claessens, S. and E. Perotti (2007), 'Finance and Inequality: Channels and Evidence', Journal of Comparative Economics, 35(4): 748-773.

Creane, S., R. Goyal, A. Mobarak and R. Sab (2003), 'Financial Development in the Middle East and North Africa', Finance and Development, 40(1): 28.

Dabla-Norris, E. and N. Srivisal (2013), Revisiting the Link between Finance and Macroeconomic Volatility. IMF Working Paper 13/29. Washington: International Monetary Fund (January).

Degryse, H. and S. Ongena (2005), 'Distance, Lending Relationships, and Competition', Journal of Finance, 60(1): 231-266.

Demirguc-Kunt, A., L. Klapper, S. Ansar and A. Jagati (2017), Making It Easier to Apply for a Bank Account: A Study of the Indian Market, Policy Research Working Paper. Washington, DC, World Bank.

Demirgüç-Kunt, A., L. Klapper, D. Singer, S. Ansar and J. Hess (2018), The Global Findex Database 2017: Measuring Financial Inclusion and the Fintech Revolution, Washington, DC: World Bank.

Démurger, S. (2001), 'Infrastructure Development and Economic Growth: An Explanation for Regional Disparities in China?', Journal of Comparative Economics, 29(1): 95-117.

De Soto, H. (2000), The Mystery of Capital: Why Capitalism Triumphs in the West and Fails Everywhere Else, New York: Basic Books, and London: Bantam Press/Random House.

Dholakia, R. (1994), 'Spatial Dimension of Acceleration of Economic Growth in India', Economic and Political Weekly, XXIX (35), August 21.

Dreze, J. and A. Sen (2013), An Uncertain Glory: India and its Contradictions, London: Allen Lane.

Eichengreen, E. and P. Gupta (2012), The global financial crisis and Indian banks: survival of the fittest? https://mpra.ub.unimuenchen.de/43365/1/MPRA_paper_43365.pdf

Esmara, H. (1975), 'Regional Income Disparities', Bulletin of Indonesian Economic Studies, 11(1): 41-57.

Fafchamps, M. and M. Schündeln (2013), 'Local Financial Development and Firm Performance: Evidence from Morocco', Journal of Development Economics, 103(2013): 15-28.

Felsenstein, D. and B. Portnov (2005), Regional Disparities in Small Countries, Berlin: Springer.

Field, E. (2007), 'Entitled to Work: Urban Property Rights and Labor Supply in Peru', Quarterly Journal of Economics, 122(4): 1561-1602.

Frankel, F. (2005), India's Political Economy: 1947-2004, New York: Oxford University Press.

Gormley, T. A. (2010), 'The Impact of Foreign Bank Entry in Emerging Markets: Evidence from India', Journal of Financial Intermediation, 19(1): 26-51.

Greif, A. (2006), Institutions and the Path to the Modern Economy: Lessons From Medieval Trade (Political Economy of Institutions and Decisions), Cambridge: Cambridge University Press.

Holcombe, R. G. and C. J. Boudreaux (2016), 'Market Institutions and Income Inequality', Journal of Institutional Economics, 12(2): 263-276.

Hornbeck, R. (2010), 'Barbed Wire: Property Rights and Agricultural Development', Quarterly Journal of Economics, 125(2): 767-810.

IMF (2020), Public Banks' Support to Households and Firms, Special Series on Fiscal Policies to Respond to COVID-19, Fiscal Affairs, International Monetary Fund, Washington, DC.

Jalilian, H. and C. Kirkpatrick (2005), 'Does Financial Development Contribute to Poverty Reduction?', Journal of Development Studies, 41(4): 636-656.

Jayaratne, J. and P. E. Strahan (1996), 'The Finance-Growth Nexus: Evidence From Bank Branch Deregulation', The Quarterly Journal of Economics, 111(3): 639-670.

Joumard, I., H. Morgavi and H. Bourrousse (2017), Achieving strong and balanced regional development in India, OECD Economics Department Working Papers, No. 1412, Paris: OECD Publishing, https://doi.org/10.1787/92fd16d9-en.

Kanbur, R. and A. Venables (2005), Spatial Inequality and Development, New York: Oxford University Press.

Kanbur, R. and X. Zhang (2005), 'Fifty Years of Regional Inequality in China: A Journey through Central Planning, Reform, and Openness', Review of Development Economics, 9(1): 87-106.

Kaur, J. and Silony (2011), 'Penetration and Growth of Banking in Punjab During Post Reforms Era', International Journal of Financial Management; New Delhi, 1(4), 23-45.

Kohli, R. (1999), 'Rural Bank Branches and Financial Reform', Economic and Political Weekly, Jan. 16-29, Vol. 34, No. 3/4, Money, Banking and Finance (Jan. 16-29, 1999), pp. 169-174. 
Kim, S. (2009), 'Institutions and US Regional Development: A Study of Massachusetts and Virginia', Journal of Institutional Economics, 5(2), 181-205.

Kim, S. (2017), 'Institutions and US Regional Development: A Study of Massachusetts and Virginia', Journal of Institutional Economics (2009), 5(2): 181-205.

Kimura, Y. (2011), Property Rights Improvement and Credit Reallocation: Theory and Evidence from Urban India

Kumar, N. (2013), 'Financial Inclusion and its Determinants: Evidence From India', Journal of Financial Economic Policy, 5 (1): 4-19.

Kurian, N. J. (2000), 'Widening Regional Disparities in India: Some Indicators', Economic \& Political Weekly, 35(7): 538-550.

Levine, R. (1997), 'Financial Development and Economic Growth: Views and Agenda', Journal of Economic Literature, 35(2): 688-726.

Mohan, R. and P. Ray (2017), Indian Financial Sector: Structure, Trends and Turns. IMF Working Paper. Washington, DC, International Monetary Fund.

Narasimham, M. (1991), Report of the Committee on the Financial System (Report). New Delhi: Ministry of Finance, Government of India.

Narayana, D. (2000), 'Banking Sector Reforms and the Emerging Patterns in Commercial Credit Deployment in India', Review of Development and Change, 5(2): 248-267.

Nayyar, D. (2015), 'Birth, Life and Death of Development Finance Institutions in India', Economic \& Political Weekly, L(33): 51-60.

Nirola N. and S. Sahu (2019), 'The Interactive Impact of Government Size and Quality of Institutions on Economic GrowthEvidence From the States of India', Heliyon, 5(3), e01352.

OPHI (2017), India Country Briefing, Multidimensional Poverty Index Data Bank. OPHI, University of Oxford. www.ophi. org.uk/multidimensional-poverty-index/mpi-country-briefings/.

Oura, H. (2008), Financial development and growth in India: a growing tiger in a cage?, IMF Working paper 08/79, Washington, DC: IMF

Pal, R. (2009), 'Outreach of Banking Services, Infrastructure Penetration, Labour Regulation and Industrial Growth: Evidence From Indian States', Retrieved June 2, 2015, from http://www.igidr.ac.in/conf/money/mfc-11/Pal_Rupayan.pdf.

Panizza, U. (2012), 'Finance and Economic Development', International Development Policy, 3(3): 141-160.

Peng, J., J. He, Z. Li, Y. Yi and N. Groenewold (2010), 'Regional Finance and Regional Disparities in China', Australian Economic Papers, 49(4), 301-322.

Pickety, T. (2014), Capital in the Twenty-First Century, Cambridge: Harvard University Press.

Prager, J. and J. Thisse (2012), Economic Geography and the Unequal Development of Regions, London: Routledge.

Purfield, C. (2006), Mind the Gap- Is Economic Growth in India Leaving Some States Behind?, Washington, D.C.: International Monetary Fund.

Rajesh Raj, S. N., K. Sen and V. Kathuria (2014), 'Does Banking Development Matter for New Firm Creation in the Informal Sector? Evidence From India', Review of Development Finance, 4(1): 38-49.

Rao, M. (2020), Institutional Factors of Credit Allocation: Examining the Role of Judicial Capacity and Bankruptcy Reforms, http://manaswinirao.com/files/paper2_dissertation.pdf

Rao, M., R.T. Shand and K.P. Kalirajan (1999), 'Convergence of Incomes across Indian States - A Divergent View', Economic \& Political Weekly, 34(13): 769-778.

RBI (2003), Annual Report, 2002-03. Mumbai, India: Reserve Bank of India.

RBI (2005), Report on Trend and Progress of Banking in India 2004-05. Mumbai, India: Reserve Bank of India.

RBI (2008), Report on Currency \& Finance 2006-08, Vol. I, Reserve Bank of India, Mumbai.

RBI (2016), Report on Trend and Progress of Banking in India. Mumbai, Reserve Bank of India.

RBI (2020a), Master Directions - Priority Sector Lending (PSL) - Targets and Classification, Reserve Bank of India, Mumbai, https://www.rbi.org.in/Scripts/BS_ViewMasDirections.aspx?id=11959

RBI (2020b), Report on Trend and Progress of Banking in India. Mumbai, Reserve Bank of India.

Robock, S. H. (1960), 'Regional and National Economic Development in India', Papers in Regional Science, 6(1): 65-81.

Sachs, J., N. Bajpai and A. Ramiah (2002), Understanding Regional Economic Growth in India, Cambridge, MA, USA, Center for International Development, Harvard University: 1-45.

Sarma, M. and J. Pais (2011), 'Financial Inclusion and Development', Journal of International Development, 23(5): 613-628.

Sarma, M. and A. Prashad (2016), 'Do Foreign Banks in India Indulge in “Cream Skimming”?', Economic \& Political Weekly, LI(12): 120-125.

Sharda, G., N. Swamy and C. Singh (2014), Impact of Foreign Banks on the Indian Economy. Working Paper 451. Indian Institute of Management, Bangalore.

Sharma, S. (2008), Capital Immobility and Regional Inequality: Evidence from India. Retrieved February 9, 2017, from https://www.enterprisesurveys.org/ /media/GIAWB/EnterpriseSurveys/Documents/ResearchPapers/Capital-ImmobilityIndia.pdf.

Shergill, B. S. and R. Kaur (2019), Rural Economy, State and Public Policy Exploring the Rural Crisis of Indian Punjab, Economic \& Political Weekly, 54: 26-27, 29 Jun. 
Shete, N. B. (2002), 'Priority Sector Advances of Banks during the Post-Reform Period', Prajnan, 31(1): 21-37.

Singh, L. and S. Singh (2002), Deceleration of Economic Growth in Punjab: Evidence, Explanation, and a Way-Out, Economic and Political Weekly, Feb. 9-15, 37: 6, 579-586

Social Progress Index (2017), Social Progress Index: States of India 2017. Retrieved from https://socialprogress.in/wp-content/ uploads/2017/10/SPI_2017_Findings.pdf

Stiglitz, J. (2013), The Price of Inequality, London: Penguin.

Stiglitz, J. (2015), The Great Divide, London: Penguin.

Svirydzenka, K. (2016), Introducing a New Broad-based Index of Financial Development. IMF Working Paper WP/16/5. Washington, DC, International Monetary Fund.

Tulasi, G., R. Goliat and M. Sethi (2017), 'Involuntary Exclusion and the Formal Financial Sector', Economic \& Political Weekly, LII(36): 67-72.

UNDP (2009), Human Development Report 2009: Overcoming Barriers: Human Mobility and Development, New York: United Nations Development Programme.

Williamson, J. G. (1965), 'Regional Inequality and the Process of Economic Development: A Description of the Patterns', Economic Development and Cultural Change, 13(4): 3-45.

World Economic Forum (2012), Financial Development Report 2012, Davos: World Economic Forum.

Yamamoto, D. (2007), 'Scales of Regional Income Disparities in the USA, 1955-2003', Journal of Economic Geography, 8(1): 79-103.

Yeyati, E. L., A. Micco and U. Panizza (2005), 'State-Owned Banks: Do They Promote or Depress Financial Development and Economic Growth?', Background paper prepared for the conference on Public Banks in Latin America: Myths and Reality Inter-American Development Bank, February 25.

Yeyati, E., A. Micco and U. Panizza (2007), 'A Reappraisal of State-Owned banks', Economia, 7(2): $209-247$.

Younas, J. (2009), 'Does Institutional Quality Affect Capital Mobility: Evidence From Developing Countries', Journal of Institutional Economics, 5(2): 207-223.

Zeng, D.-Z. (2016), 'Capital Mobility and Spatial Inequalities in Income and Industrial Location', The Journal of Economic Inequality, 14(1): 109-128.

Zhang, Q., R. Arora and S. Colombage (2021), 'The Determinants of Bank Branch Location in India: An Empirical investigation', International Journal of Bank Marketing, doi:10.1108/IJBM-07-2020-0395.

Zou, K. and J. He (2018), 'Intra-Provincial Financial Disparity, Economic Disparity, and Regional Development in China: Evidence from Prefecture-Level City Data', Emerging Markets Finance and Trade, 54(13): 3064-3080 (October).

\section{Appendix A}

Table A1. Classification of states based on per capita income

\begin{tabular}{ll}
\hline Leading states & Lagging states \\
\hline Gujarat & Assam \\
\hline Haryana & Bihar \\
\hline Himachal Pradesh & Jharkhand \\
\hline Karnataka & Madhya Pradesh \\
\hline Kerala & Chattisgarh \\
\hline Maharashtra & Orissa \\
\hline Punjab & Rajasthan \\
\hline Tamilnadu & Uttar Pradesh \\
\hline Andhra Pradesh & West Bengal \\
\hline Arunachal Pradesh & Manipur \\
\hline & Meghalaya \\
\hline & Mizoram \\
\hline
\end{tabular}

Source: Arora and Wondemu (2018). 
Table A2. Banking development index values

\begin{tabular}{|c|c|c|c|c|c|c|c|c|c|c|c|c|c|}
\hline States & 1996 & 1997 & 1998 & 1999 & 2000 & 2001 & 2002 & 2003 & 2004 & 2005 & 2006 & 2007 & 2008 \\
\hline Gujarat & 0.289 & 0.309 & 0.338 & 0.381 & 0.340 & 0.340 & 0.308 & 0.353 & 0.370 & 0.402 & 0.399 & 0.390 & 0.400 \\
\hline Haryana & 0.283 & 0.308 & 0.414 & 0.305 & 0.301 & 0.323 & 0.297 & 0.347 & 0.350 & 0.370 & 0.405 & 0.413 & 0.388 \\
\hline HP & 0.345 & 0.346 & 0.361 & 0.367 & 0.359 & 0.369 & 0.324 & 0.358 & 0.357 & 0.348 & 0.350 & 0.354 & 0.365 \\
\hline Karnataka & 0.441 & 0.454 & 0.471 & 0.524 & 0.471 & 0.501 & 0.548 & 0.625 & 0.632 & 0.676 & 0.692 & 0.711 & 0.685 \\
\hline Kerala & 0.591 & 0.582 & 0.591 & 0.614 & 0.563 & 0.564 & 0.503 & 0.562 & 0.583 & 0.556 & 0.567 & 0.533 & 0.566 \\
\hline Maharsahtra & 0.768 & 0.772 & 0.765 & 0.836 & 0.780 & 0.783 & 0.821 & 0.837 & 0.890 & 0.942 & 0.967 & 0.984 & 0.999 \\
\hline Punjab & 0.454 & 0.470 & 0.468 & 0.478 & 0.458 & 0.464 & 0.434 & 0.480 & 0.495 & 0.506 & 0.505 & 0.496 & 0.495 \\
\hline Tamilnadu & 0.555 & 0.576 & 0.593 & 0.597 & 0.534 & 0.581 & 0.515 & 0.641 & 0.679 & 0.655 & 0.666 & 0.669 & 0.654 \\
\hline $\mathrm{AP}$ & 0.296 & 0.308 & 0.325 & 0.376 & 0.333 & 0.345 & 0.311 & 0.368 & 0.388 & 0.415 & 0.404 & 0.413 & 0.429 \\
\hline Arunachal & 0.391 & 0.321 & 0.155 & 0.315 & 0.269 & 0.141 & 0.334 & 0.102 & 0.142 & 0.378 & 0.227 & 0.216 & 0.221 \\
\hline Assam & 0.140 & 0.145 & 0.152 & 0.130 & 0.134 & 0.157 & 0.164 & 0.182 & 0.166 & 0.162 & 0.158 & 0.147 & 0.144 \\
\hline Bihar & 0.183 & 0.193 & 0.193 & 0.263 & 0.238 & 0.116 & 0.072 & 0.132 & 0.124 & 0.089 & 0.072 & 0.080 & 0.065 \\
\hline Jharkhand & & & & & & 0.240 & 0.264 & 0.285 & 0.177 & 0.300 & 0.209 & 0.185 & 0.192 \\
\hline MP & 0.213 & 0.218 & 0.223 & 0.303 & 0.213 & 0.169 & 0.172 & 0.175 & 0.180 & 0.250 & 0.240 & 0.224 & 0.226 \\
\hline Chattisgarh & & & & & & 0.110 & 0.126 & 0.135 & 0.151 & 0.153 & 0.142 & 0.170 & 0.194 \\
\hline Odishha & 0.130 & 0.114 & 0.162 & 0.221 & 0.166 & 0.180 & 0.194 & 0.203 & 0.201 & 0.270 & 0.248 & 0.234 & 0.254 \\
\hline Rajasthan & 0.163 & 0.170 & 0.171 & 0.256 & 0.175 & 0.282 & 0.228 & 0.213 & 0.226 & 0.242 & 0.225 & 0.232 & 0.236 \\
\hline UP & 0.184 & 0.192 & 0.203 & 0.194 & 0.198 & 0.188 & 0.254 & 0.222 & 0.237 & 0.240 & 0.236 & 0.226 & 0.233 \\
\hline West Bengal & 0.390 & 0.412 & 0.447 & 0.374 & 0.383 & 0.399 & 0.350 & 0.396 & 0.378 & 0.375 & 0.368 & 0.353 & 0.322 \\
\hline Manipur & 0.000 & 0.000 & 0.000 & 0.000 & 0.000 & 0.002 & 0.000 & 0.000 & 0.000 & 0.004 & 0.000 & 0.000 & 0.001 \\
\hline Meghalaya & 0.278 & 0.257 & 0.247 & 0.231 & 0.240 & 0.254 & 0.262 & 0.281 & 0.326 & 0.406 & 0.451 & 0.219 & 0.308 \\
\hline Mizoram & 0.327 & 0.311 & 0.241 & 0.255 & 0.155 & 0.094 & 0.099 & 0.120 & 0.130 & 0.382 & 0.180 & 0.185 & 0.255 \\
\hline Nagaland & 0.123 & 0.128 & 0.099 & 0.100 & 0.080 & 0.089 & 0.088 & 0.057 & 0.078 & 0.059 & 0.048 & 0.095 & 0.032 \\
\hline Tripura & 0.407 & 0.397 & 0.406 & 0.369 & 0.395 & 0.330 & 0.383 & 0.406 & 0.366 & 0.168 & 0.214 & 0.143 & 0.154 \\
\hline J\&K & 0.436 & 0.377 & 0.443 & 0.413 & 0.445 & 0.464 & 0.411 & 0.400 & 0.399 & 0.392 & 0.369 & 0.366 & 0.347 \\
\hline
\end{tabular}


Table A3. Banking development index values

\begin{tabular}{|c|c|c|c|c|c|c|c|}
\hline States & 2009 & 2010 & 2011 & 2012 & 2013 & 2014 & 2015 \\
\hline Gujarat & 0.309 & 0.278 & 0.334 & 0.342 & 0.352 & 0.351 & 0.370 \\
\hline Haryana & 0.333 & 0.350 & 0.406 & 0.415 & 0.413 & 0.414 & 0.432 \\
\hline HP & 0.398 & 0.450 & 0.445 & 0.456 & 0.442 & 0.446 & 0.473 \\
\hline Karnataka & 0.560 & 0.590 & 0.601 & 0.584 & 0.567 & 0.569 & 0.585 \\
\hline Kerala & 0.438 & 0.422 & 0.476 & 0.491 & 0.504 & 0.507 & 0.534 \\
\hline Maharsahtra & 1.000 & 1.000 & 1.000 & 1.000 & 1.000 & 0.998 & 0.989 \\
\hline Punjab & 0.418 & 0.390 & 0.438 & 0.448 & 0.455 & 0.462 & 0.478 \\
\hline Tamilnadu & 0.580 & 0.633 & 0.623 & 0.684 & 0.728 & 0.730 & 0.719 \\
\hline AP & 0.484 & 0.482 & 0.526 & 0.550 & 0.544 & 0.546 & 0.198 \\
\hline Arunachal Pradesh & 0.218 & 0.253 & 0.263 & 0.281 & 0.253 & 0.267 & 0.259 \\
\hline Assam & 0.132 & 0.131 & 0.172 & 0.164 & 0.138 & 0.156 & 0.399 \\
\hline Bihar & 0.064 & 0.113 & 0.073 & 0.059 & 0.111 & 0.043 & 0.060 \\
\hline Jharkhand & 0.222 & 0.236 & 0.239 & 0.238 & 0.240 & 0.229 & 0.234 \\
\hline MP & 0.184 & 0.174 & 0.197 & 0.201 & 0.186 & 0.200 & 0.230 \\
\hline Chattisgarh & 0.142 & 0.154 & 0.172 & 0.194 & 0.147 & 0.181 & 0.206 \\
\hline Odishha & 0.207 & 0.215 & 0.246 & 0.251 & 0.275 & 0.251 & 0.261 \\
\hline Rajasthan & 0.194 & 0.172 & 0.211 & 0.213 & 0.206 & 0.190 & 0.236 \\
\hline UP & 0.190 & 0.165 & 0.204 & 0.203 & 0.179 & 0.188 & 0.208 \\
\hline West Bengal & 0.399 & 0.384 & 0.421 & 0.420 & 0.416 & 0.414 & 0.415 \\
\hline Manipur & 0.102 & 0.012 & 0.048 & 0.055 & 0.068 & 0.079 & 0.076 \\
\hline Meghalaya & 0.214 & 0.264 & 0.268 & 0.283 & 0.282 & 0.290 & 0.299 \\
\hline Mizoram & 0.210 & 0.273 & 0.257 & 0.286 & 0.250 & 0.254 & 0.307 \\
\hline Nagaland & 0.158 & 0.147 & 0.153 & 0.150 & 0.137 & 0.142 & 0.101 \\
\hline Tripura & 0.248 & 0.272 & 0.255 & 0.277 & 0.239 & 0.244 & 0.305 \\
\hline$J \& K$ & 0.406 & 0.466 & 0.441 & 0.462 & 0.495 & 0.500 & 0.500 \\
\hline
\end{tabular}

Source: Computed by the authors.

Cite this article: Arora RU, Anand PB (2021). Regional financial disparity in India: can it be measured? Journal of Institutional Economics 17, 836-860. https://doi.org/10.1017/S1744137421000291 